A DETAILED analysis of the surface waters of the Eastern Baltic and the Gulf of Finland has now provided a theoretical basis for an experiment begun with field trials in 1969-the use of these water masses as a source of irrigation.

The first trials took place on the island of Mukku (Estonian SSR). The irrigated land yielded the "hoped-for" results, and in the spring of 1970 the research programme was started by the Irrigation Section of the V.I. Lenin All-Union Academy of Agricultural Sciences. A systematic study was made of the salinity and mineral content of the coastal waters of northern and western Estonia and of the Khiiumaa and Sarremaa. In all, 63 coastal 'points' were tested, samples being taken from depths of $50 \mathrm{~cm}$ to $1 \mathrm{~m}$. In all, 664 specimens of water were analysed.

According to the report published in Pravda (July 25, 1974), the average salinity for the area was $1.5-2.0 \mathrm{~g} \mathrm{I}^{-1}$ ("almost fit for drinking"-a not surprising result, since the low salinity of the Baltic is a well known phenomenon, particularly as regards the $30-50 \mathrm{~cm}$ and 50-60 cm layers). Also in 1970, field tests

\section{Sea water for irrigation}

by our Soviet Correspondent

were begun on three collective farms having contrasting soils (sandy, arigillaceous and soddy-calcareous), using crops of perennial grass, barley, potatoes, swedes, early and late cabbage, table beet, cucumbers and so on. During the four years of the tests, good results have been obtained with pasture grasses, barley and a number of vegetables. Subsequent soil tests indicated the introduction of "a fairly considerable quantity" of dissolved mineral salts into the soil; in particular, after one summer of irrigation with sea water, the sodium content of the arable soil of the "Linnamyae" state farm (of soddy-calcareous type) rose from $4-10 \mathrm{mg}$ per $100 \mathrm{~g}$ soil to $30 \mathrm{mg}$ per $100 \mathrm{~g}$ soil. In 1971-73 further tests were carried out to determine the effect of the increased salinity on the soil microflora.

According to the Pravda report, which is signed by no less a person than O. Valing, Chairman of the State Com- mittee of the Council of Ministers of the Estonian SSR on Land Reclamation and Water Economy, the results indicate that, "with a proper choice of crops and agricultural technology", the use of sea water in irrigation can prove an important adjunct to Estonian agriculture. Yet some facts, which he calls "curious" seem to indicate the need for caution in assessing the nutritional aspects of these results. Thus barley grows taller and gives a heavier grain yield, when grown on sea water, but the protein content is "somewhat" lower. In the case of cabbage and beet, the sugar content of the sea water crop is higher. And the presentation of the report in Pravda, on page 2, which is normally reserved for "party" news (science reports normally are found on page 3 or page 6) would suggest that the original decision to use sea water might well have been of political, rather than scientific, origin. When one recalls the disastrous effect on Soviet agriculture, and Soviet science as a whole, of another such political decision-Lysenkoism-one can only await future news from the fields of Estonia with a certain caution.
Frederick Dainton, chairman of the University Grants Commission, referred to the alienation from science caused by its unacceptable relationship with power (often misused), and its lack of concern for people. The exploitation of science in the military context and the connection between industrialisation and pollution were cited as examples. Sir Frederick believed that science should be taught in the universities as a humanity: not as an instrument of control over the environment, but as a subject of interest for enquiring minds.

It was reassuring to find that Britain is not alone in experiencing difficulties, the most frequently recurring theme being the effects of inflation which militate so strongly against educational interests. Relief from the prevailing atmosphere of doom was given by $\mathrm{Dr}$ W. B. Lewis in describing changes in science at Canadian universities. Here, one felt, was a country with security in its possession of large natural resources and confidence in its future. Despite earlier predictions that the need for scientists would decline, the numbers of graduates and PhDs had increased enormously in 1973 and all were now in relevant employment. Asked what had made such changes nossible, Dr Lewis stressed the prime importance of cheap energy which in Canada was not simply derived from hydroelectric sources. The advanced energy programme was capable of producing electricity even more cheaply than from water power.

Dr J. B. Adams of CRN believed the qualities required of graduates were job flexibility and the abilities to plan, budget and acquire new technologies. He praised the breadth of approach found in general applied physics degrees and made the interesting observation that $40 \%$ of the engineers in his organisation were in fact physics graduates. The point was taken up by Professor H. B. G, Casimir, the President of the Royal Netherlands Academy of Sciences and Letters who believed that the only purpose of specialisation was to inculate the ability to specialise; the specific subject was only of secondary importance. The three year degree in England was too short to make specialisation within it a sound proposition and he suggested that industry in this country should be prepared to recruit far more PhDs.

Sir Frederick Dainton also had some harsh things to say about specialisation in the first degree. A curriculum based on professional requirements was the easy way out for university teachers who were subject specialists themselves. Yet the factual and professional content of a degree was ephemeral. What was needed was the ability to think logically and transmit ideas clearly. Science should be taught in a spirit of enquiry and more time should be devoted by faculty to reflective consideration of their subjects and the development of discovery-based learning techniques, instead of trivial research.
Crisis is Greek for decision. Predictably the conference did not produce one, though it did illuminate some of the underlying problems of university science. With issues of such complexity and gravity one wished the organisers had provided more opportunity for discussion in smaller groups. Half-hour discussions with 450 people all facing in the same direction rarely produce anything of substance. And what of the school-teachers, invited in large numbers yet unrepresented by speakers? They work amongst shifting sands; the science departments get poorer recruitment every year and the competition from what they see as undemanding soft options gets fiercer. At a time when even previously highly selective university departments are touting for undergraduates in the schools they needed some guidance on whether to try and stimulate schoolchildren to take up science or steer them away from it. None of the speakers, one felt, took this section of the audience very seriously.

What did emerge was the fundamental need to recover the ability to plan in the long term. Only in this way can there be orderly development and the maintaining of morale. Inflation has negated planning, and if it cannot be cured we must at least learn to live with it more successfully. Meanwhile we seem confined to the world of Kafka's aphorism: "There is an end but no way; what we call the way is shilly-shallying". 